\title{
Improving Tourism Destination Management Through Sustainable Tourism Development Model A Case Study on TSR
}

\author{
Edy Sahputra Sitepu
}

Administrasi Niaga, Politeknik Negeri Medan

Corresponding author: eddiestp@gmail.com

\section{ARTICLE INFO \\ Received \\ 17 January 2019 \\ Accepted \\ 07 September 2019 \\ Available online \\ 30 September 2019}

ABSTRACT

As a priority destination, Lake Toba area should immediately clean up so as not to lag behind compared to other destinations. One important indicator of the good governance of tourism in this priority destination is, when the destination has run the management and development of tourism/destination with the principles of Sustainable Tourism Development (STD). According to Global Sustainable Tourism Council (GSTC) the principles that must be met, among others are; 1) demonstrating effective sustainable management, 2) maximizing social and economic benefit to the local community and minimizing negative impacts; 3) maximizing benefit to cultural heritage and minimizing negative impacts; and 4) maximize benefit to the environtment and minimizing negative impacts in accordance with Permenpar No .14 / 2016. Given the importance of STD implementation in the Lake Toba area, this research tries to assess and influence one of the important destinations in Lake Toba area, namely Taman Simalem Resort (TSR) located right on the edge of Lake Toba, Merek Sub District, Karo District. It is expected that by encouraging TSR in applying STD, TSR can become a local champion and become model of STD application in Toba Lake Area.

Keywords: Sustainable Tourism Development, STD Criteria, Taman Simalem Resort (TSR)

\section{INTRODUCTION}

\section{Background}

Upon completion in 2015 the Millennium Development Goals (MDGs) development concept has been continued with a new concept called Sustainable Development Goals (SDGs) and is valid from early 2016 to 2030 (Nam, 2016; Wysokińska, 2017). Along with the declaration of SDGs, as one of the countries that adopt SDGs, the Indonesian government also provides a proactive response. In the same year as the launching of SDGs, where the government through the Ministry of Tourism RI 
launched the SDGS program in the tourism sector known as the Sustainable Tourism Development (STD) program. In 2017 , to begin assessing the performance of sustainable tourism development the Ministry of Tourism has also implemented the Indonesia Sustainable Tourism Award - ISTA (Kemenpar, 2016).

In the previous year, Kemenpar RI has been holding 20 districts / cities that states are ready to carry out the development of tourism destinations with the principle of sustainable tourism development, among others; 1) Kabupaten Lombok Barat, 2) Kabupaten Wakatobi, 3) Kabupaten Berau, 4) Kabupaten Raja Ampat, 5) Kabupaten Kepulauan Morotai, 6) Kabupaten Palangkaraya, 7) Kabupaten Hulu Sungai Selatan, 8) Kota Pontianak, 9) Kabupaten Biak Numfor, 10) Kota Ternate, 11) Kota Sleman, 12) Kabupaten Magelang, 13) Kabupaten Pangandaran, 14) Kabupaten Probolinggo, 15) Kabupaten Pesisir Selatan, 16) Kota Sabang, 17) Kota Bintan, 18) Kota Medan, 19) Kabupaten Belitung and 20) Kota Palembang (Dewipule, 2015).

In addition to the determination of 20 pilot project destinations for STD implementation, Kemenpar RI also set 10 national priority tourism destinations, consisting of;1) Danau Toba, 2) Tanjung Kelayang, 3) Kepulauan Seribu, 4) http://ojs.unud.ac.id/index.php/eot
Tanjung Lesung, 5) Borobudur, 6) BromoTengger-Semeru, 7) Mandalika, 8) Wakatobi, 9) Pulau Morotai dan 10) Labuan Bajo (Ibo, 2015; Kominfo, 2016). As one of the priority destinations, Lake Toba area certainly must be cleaned up immediately so as not to lag behind compared to other destinations. The important indicator of the good governance of tourism in the priority destination is that the destination has run the management and development of tourism / destination with the principles of Sustainable Tourism Development (STD). The STD Principles that must be met refers to the Global Sustainable Tourism Council (GSTC). These principles are then adopted to bePermenpar No.14/2016 (Kemenpar, 2016; GSTC, 2017).

In relation to the above mentioned things, this paper will further report the results of exploring applied research. How the application of STD can be improved in quality with mentoring activities, where research has been done on one of the important destinations in Lake Toba area of Simalem Resort Park (TSR) located right on the edge of Lake Toba, Kecamatan Merek, Kabupaten Karo. 


\section{LITERATURE REVIEW}

Sustainable development became one of the important keywords underlying the framework of development around the world today, departing from the realization that the earth is not merely belonging to the current generation. The concept of original sustainability development is a concept developed by environmentalists who surfaced in the 1970s (Liu, 2003).

Explicitly the idea of sustainable development first became the concern of the Union for the Conservation of Natura and Natural Resources (IUCN, 1980) in the document World Conservation Strategy. In 1987, sustainable development was conceptualized as a merger of two schools of thought namely; theory of development and sustainable environmental management. Where the merger of the two concepts was first echoed in the Brundtland Report entitled 'Our Common Future'. Furthermore, sustainable development is described as 'development that meets the needs of today's generations without compromising the ability of future generations to meet their needs'. The same document also stipulates that development activities may be said to be sustainable development activities (in a region, country or world) if, the total amount of resources, labor, reproducible capital goods, natural http://ojs.unud.ac.id/index.php/eot resources, consumable resources is not decreases over time (WECD, 1987).

Sustainable development has a very diverse definition, Steer \& WadeGery (1993) reveals at least more than 70 definitions of sustainable development. Inevitably, in its development, people from various fields then use the term sustainable development in different contexts and approaches (Heinen, 1994). Nevertheless, as revealed Lele (1991), the philosophy of sustainable development can generally be explored by looking at the term 'development' and 'sustainability'. Sustainable development is defined as a concept that introduces structural transformation to society so that development activities (physically and socially) do not threaten the desired growth, through social unrest, environmental pollution or depletion of resources. If we examine further, the same thing also expressed by Fennell (2014), Tribe (2011) dan Paunović \& Jovanović (2017).

Over time, sustainable development came into being in the socalled Millennium Development Goals (MDGs) agreed at the UN Millennium Summit in New York in 2000, attended by 189 countries and signed by 147 heads of government and valid until 2015 (Hulme, 2009). The 8 general objectives of the 
MDGs include; 1) eliminating poverty, 2) realizing basic education for all people, 3) promoting gender equality and 4) empowering women, 5) reducing child mortality, 6) improving maternal health, fighting against HIV / AIDS, 7) ensuring environmental sustainability and 8) developing a global partnership for development (Wysokinska, 2017).

Then in September 2015, officially at the United Nations Sustainable Development Summit meeting in New York, attended by more than 190 countries, a new chapter for sustainable development with a concept called Sustainable Development Goals (SDGs) to continue the MDGs up to 2030. In general, 17 objectives of SDGs can be grouped into four pillars, namely 1) human development, 2) economic development, 3) environmental development, and 4) governance. There are also 5 foundations of SDGs namely; 1) human, 2) planet, 3) prosperity, 4) peace, and 5) partnership (Wysokińska, 2017).

It was also stated that there are 17 objectives of SDGs, among others related to issues of poverty, hunger, health and welfare, education, gender equality and women's empowerment, water and sanitation management, energy, economic growth, infrastructure, intra- and interstate gaps, production and consumption, climate change, marine conservation, terrestrial ecosystems, justice for all people and partnerships in which relevant indicators are needed (Hák, Janoušková dan Moldan, 2016).

One of the most active sectors to internalize the concept of sustainable development is the tourism sector, known as the concept of sustainable tourism development (STD). This sustainable tourism has become a popular discourse of the 1980s, although it is still patchy, has not been integrated and assumptions that still tend to be wrong (Liu, 2003). Similar to sustainable development, sustainable tourism development also has a diverse definition according to experts, as suggested by Butler (1999), Lane (1994), Hunter (1995) and others.

The UNWTO defines sustainable tourism development as an activity to meet the diverse needs of tourists at this time and the needs of the relevant tourist destination areas, while still protecting and enhancing opportunities and resources for the future. It is considered to lead to the management of all resources in such a way that economic, social and aesthetic needs can be met while maintaining cultural integrity, important ecological processes, biodiversity and life support systems (UNEP \& UNWTO, 2005). 
In Indonesia this concept began to be introduced since early 2016. Along with the declaration of SDGs, the government of Indonesia through the Tourism Ministry of Indonesia made a pilot project of tourism development with the concept of sustainable tourism development. Tourism Ministry of Indonesia has partnered with 20 districts / municipalities committed to implementing sustainable tourism practices. Even to support the program Tourism Ministry of Indonesia has issued Permenpar No.14 / 2016 on Guidelines for Sustainable Tourism Development Destination (Kemenpar, 2016).

\section{Criteria and Indicators}

Based on The Global Sustainaible Tourism Council (GSTC) there are 4 pillars to find tourist places, hotels or tour operators who have or have not implemented the development yet. The four pillars elsewhere; a) demonstrate management of sustainable destinations, $b$ ) maximize economic benefits for host communities and minimize negative impacts, c) maximize benefits for communities, visitors, and cultures; minimize negative impacts and d) maximize benefits for the environment and minimize negative impacts. Steps to establish ISO code of conduct and code of ISEAL alliance standards, international http://ojs.unud.ac.id/index.php/eot bodies providing assistance for development and development of standards for sectors (GSTC, 2017).

By the Government of Indonesia, through the Ministry of Tourism, the four pillars, along with the criteria for sustainable tourism development of GSTC is then adopted into the standard of management of sustainable tourism destinations and set forth in Permenpar No.14 / 2016. The scope of sustainable tourism destinations set forth in Permenpar No.14 / 2016, among others, includes; a) management of sustainable tourism destinations, b) economic utilization for local communities, c) cultural preservation for communities and visitors and d) environmental preservation (Kemenpar, 2016).

A similar approach in assessing sustainable tourism development is also underway (Bassi dan Sheng, 2012), OECD (2014), and Seaford \& Jeffrey (2015). Castellani \& Sala (2010) using sustainable performance index for tourism policy development, Blancas, González, LozanoOyola, \& Pérez (2010) using a system of sustainable tourism indicators. Ritchie \& Crouch (2003) suggests that a sustainable destination has 4 pillars, ie; a) ecological sustainability, b) economic sustainability, c) sociocultural sustainability dan d) political sustainability. While Hardy, 
Beeton, \& Pearson (2002) formulate conceptual entanglements and operational contexts of sustainable tourism incorporation consisting of 5 aspects, namely; a) economic vision, b) conservation vision, c) community vision, d) academic response and e) industry response.

\section{Previous Research}

Rizkianto \& Topowijono (2018), Nurhidayati (2007), Afriza, Kartika, \& Riyanti (2018) put forward the concept of CBT (Community Based Tourism) applied to achieve sustainable tourism management.Law, DeLacy, \& McGrath (2017), assess the application of sustainable tourism development using green economy indicator framework, while Kristjánsdóttir, Ólafsdóttir, \& Ragnarsdóttir (2018) trying to examineIntegrated sustainability indicators for tourism (ISIT). Akama \& Kieti (2007) discuss issues surrounding sustainable tourism as a tool for socioeconomic development in Kenya. Tosun (2001) presents a challenge analysis of sustainable tourism development in developing countries.

Several other researchers have also analyzed how STD implementation strategies, among others; Nowacki, Kowalczyk-Anioł, Królikowska, PstrockaRak, \& Awedyk (2018), Singh (2018) dan http://ojs.unud.ac.id/index.php/eot
Amerta, Sara, \& Bagiada (2018). The study of criteria in recent studies, among others, is put forward by; Torres-Delgado \& López Palomeque (2017), Ottenbacher, Schwebler, Metzler, \& Harrington (2018), Peng \& Tzeng (2017), Kumar et al., (2017), Dos Santos, Méxas, \& Meiriño (2017) and others.

\section{RESEARCH METHODS}

This study examines how the application of sustainable tourism development with national indicators that have been established by Tourism Ministry of Indonesia. The research was conducted in 6 months in 2017, which in the early stages performed; 1) introduction of the STD concept to TSR management and owners, and 2) developing agreements with management and owners for STD implementation; 3) implementing baseline assessment and FGD; 4) providing mentoring process; 4) conducting final assessment and FGD. In the mentoring process intervention action was done to provide strengthening on the aspect or indicators that are still weak based on the baseline assessment. Strengthening actions are conducted in the form, socialization, meetings, discussions, FGDs with TSR management and key stakeholders, improvement of administrative documents, 
the making of SOPs, improvement of behavior and others.

The variables observed among others are divided into 4 parts, namely; 1) management of sustainable tourism destinations, 2) economic utilization for local communities, 3) cultural preservation for the community and visitors and 4) environmental preservation (Kemenpar, 2016; GSTC, 2017).

Measurements are made by assessing the dimensions of the variables used, with ordinal scales; score 4 if fully fulfilled (green), score 3 partially fulfilled (blue), score 2 less fulfilled (yellow) and score 1 unfulfilled or category red (Dergibson \& Siagian, 2006) and Kemenpar (2016).

The scoring process was conducted in an FGD forum involving 24 people, among others; management of TSR (1 person), owner of TSR (1 person), Tourism Office of Karo Regency (1 person), Tourism Office of North Sumatera Province (1 person), ASITA Sumut (1 person), PHRI (1 person) (1 person), village apparatus (3 persons) around TSR (people), community leaders (2 persons), TSR (2 persons) representatives, college representatives in this case from Tourism Academy (2 persons), (2 persons), organic farmers (2 persons), police (1 person), representatives http://ojs.unud.ac.id/index.php/eot of local artists (2 persons), Balai Lingkungan Hidup (1 person). In addition to FGD researchers also conducted direct validation in the field to see the real conditions that occur.

\section{RESULTS AND DISCUSSION}

\section{Baseline Assessment}

The baseline assumption phase is carried out by conducting field visits to the TSR located in the District of Brand, Karo District. In this baseline assessment the indicators used in the application of sustainable tourism development are filled in FGD forums by involving key stakeholders (as noted in the methodology). The baseline assessment results are presented as follows:

Table 1. Results of the Implementation Baseline Assessment

\begin{tabular}{|c|c|c|c|c|c|}
\hline Criteria & $\begin{array}{l}\text { Excellent } \\
\text { (Green) }\end{array}$ & $\begin{array}{l}\text { Good } \\
\text { (Blue) }\end{array}$ & $\begin{array}{l}\text { Adequate } \\
\text { (Yellow) }\end{array}$ & $\begin{array}{l}\text { Poor } \\
\text { (Red) }\end{array}$ & Total \\
\hline $\begin{array}{l}\text { SECTION } \\
\text { A: } \\
\text { Demonstr } \\
\text { ate } \\
\text { effective } \\
\text { sustainabl } \\
\text { e } \\
\text { managem } \\
\text { ent }\end{array}$ & $0.00 \%$ & $\begin{array}{l}41.86 \\
\%\end{array}$ & $44.19 \%$ & $\begin{array}{l}13.95 \\
\%\end{array}$ & $\begin{array}{l}100 \\
\%\end{array}$ \\
\hline $\begin{array}{l}\text { SECTION } \\
\text { B: } \\
\text { Maximize } \\
\text { economic } \\
\text { benefits to } \\
\text { the host } \\
\text { communit } \\
\text { y and } \\
\text { minimize } \\
\text { negative } \\
\text { impacts }\end{array}$ & $0.00 \%$ & $\begin{array}{l}42.86 \\
\%\end{array}$ & $57.14 \%$ & $\begin{array}{l}0.00 \\
\%\end{array}$ & $\begin{array}{l}100 \\
\%\end{array}$ \\
\hline
\end{tabular}




\begin{tabular}{|c|c|c|c|c|c|}
\hline $\begin{array}{l}\text { SECTION } \\
\text { C: } \\
\text { Maximize } \\
\text { benefits to } \\
\text { communit } \\
\text { ies, } \\
\text { visitors, } \\
\text { and } \\
\text { culture; } \\
\text { minimize } \\
\text { negative } \\
\text { impacts }\end{array}$ & $0.00 \%$ & $\begin{array}{l}69.23 \\
\%\end{array}$ & $23.08 \%$ & $\begin{array}{l}7.69 \\
\%\end{array}$ & $\begin{array}{l}100 \\
\%\end{array}$ \\
\hline $\begin{array}{l}\text { SECTION } \\
\text { D: } \\
\text { Maximize } \\
\text { benefits to } \\
\text { the } \\
\text { environme } \\
\text { nt and } \\
\text { minimize } \\
\text { negative } \\
\text { impacts }\end{array}$ & $0.00 \%$ & $\begin{array}{l}46.43 \\
\%\end{array}$ & $50.00 \%$ & $\begin{array}{l}3.57 \\
\%\end{array}$ & $\begin{array}{l}100 \\
\%\end{array}$ \\
\hline Sum & $0.00 \%$ & $\begin{array}{l}49 \\
46.67 \\
\%\end{array}$ & 48 & $\begin{array}{l}8 \\
7.62 \\
\%\end{array}$ & $\begin{array}{l}105 \\
100 . \\
00 \%\end{array}$ \\
\hline
\end{tabular}

Source: FGD Results Data Processed

Based on Table 1, it is known that of the 4 STD implementation variables, there are no variables that are categorized as green and most are in blue, yellow and red categories with relatively balanced blue and yellow proportions and fewer red categories. This indicates basically the application of STD in the TSR is relatively good but still in the blue (good) and yellow areas (enough) and requires intervention to shift to green and blue categories.

From Table 1 it is also known that section A (demonstrate effective sustainable management) has 18 items $(41.86 \%)$ with well-implemented (blue) criteria, 19 items (44.19\%) with sufficient criteria (yellow) and 6 items (13.95\%) http://ojs.unud.ac.id/index.php/eot with less criteria (red). It is understandable that in general in terms of management aspects, TSR is actually good enough in implementing sustainable management. Some things that need to be improved include how the TSR can develop multiyear development plans involving public participation, TSR also has not proceeded to obtain sustainability standards, report on the development of safety and security related events, customer satisfaction reports, weaknesses of administrative documentation and etc.

In section $\mathrm{B}$ there are 0 items in green category, 19 items $(41,86 \%)$ in blue category, 19 items $(44,19 \%)$ in yellow category and 6 item $(13,95 \%)$ are in red category. The three indicators that have the highest score include on how TSR has provided support to local entrepreneurs and encourages fair trade, provides employment and career opportunities for local communities and has monitored the economic impacts of local communities but has not been well documented. Some of the indicators that are considered to be weak (having the lowest score) are related to access of local communities to enter the very limited area of TSR, awareness about tourism and knowledge about the local people's low tourism and support for local people who are deemed to be lacking well documented. 
In section $\mathrm{C}$ there are 0 items in the green category, 9 items $(69.23 \%)$ in the blue category, 3 items $(23.08 \%)$ in the yellow category and 1 item $(7.69 \%)$ are in the red category. Field findings and FGDs found that TSR has interpreted the sites in the TSR region well, in the spot activities have been made announcements, sign, site interpretation in several languages namely English, Indonesia, Karo (with script Karo). Visitor behavior has also been well observed in various activities both indoor and outdoor, as well as protection of local attractions by periodically displaying local art in cooperation with local communities. However, several things that still need to be improved on how TSR can work together with the Karo District Tourism Officework together to protect the cultural heritage, better visitor management so that it is not only visited at particular times of day and takes into account intellectual property rights (artists and local craftsmen).

While in section $\mathrm{D}$ there are 0 items in special category, 13 items $(46,43 \%)$ in good category, 14 item $(50 \%)$ in enough category and 1 item $(3,57 \%)$ in less category. In this aspect D there has been no indicator that entered in the green category. Some relatively well-done items include protection against sensitive environments, environmentally friendly transport and environmental risk control. Important things to note and have a relatively low score, among others; how TSR considers more about energy conservation, water management, and water security.

\section{Final Assessment}

Based on Table 2 it is known that from 4 STD implementation variables, there is a significant change in the final assessment result compared to the baseline assessment result. In the final assessment, most items have been included in the green category, especially in section $\mathrm{A}$ and section $\mathrm{C}$, while for section $\mathrm{B}$ and section $\mathrm{D}$ the majority of the blue criteria, this change means that there has been a significant improvement after the mentoring treatment on TSR governance.

Table 2. Results of Final Assessment of STD Application

\begin{tabular}{|c|c|c|c|c|c|}
\hline Criteria & $\begin{array}{l}\text { Excellent } \\
\text { (Green) }\end{array}$ & $\begin{array}{l}\text { Good } \\
\text { (Blue) }\end{array}$ & $\begin{array}{l}\text { Adequate } \\
\text { (Yellow) }\end{array}$ & $\begin{array}{l}\text { Po } \\
\text { or } \\
\text { (R } \\
\text { ed) }\end{array}$ & Total \\
\hline $\begin{array}{l}\text { SECTION } \\
\text { A: } \\
\text { Demonstrate } \\
\text { effective } \\
\text { sustainable } \\
\text { management }\end{array}$ & $53.49 \%$ & $\begin{array}{l}39.53 \\
\%\end{array}$ & $6.98 \%$ & $\begin{array}{l}0 . \\
00 \\
\%\end{array}$ & $\begin{array}{l}43 \\
100 \\
\%\end{array}$ \\
\hline $\begin{array}{l}\text { SECTION } \\
\text { B: Maximize } \\
\text { economic } \\
\text { benefits to } \\
\text { the host } \\
\text { community } \\
\text { and } \\
\text { minimize } \\
\text { negative } \\
\text { impacts }\end{array}$ & $42.86 \%$ & $\begin{array}{l}57.14 \\
\%\end{array}$ & $0.00 \%$ & $\begin{array}{l}0 . \\
00 \\
\%\end{array}$ & $\begin{array}{l}100 \\
\%\end{array}$ \\
\hline
\end{tabular}




\begin{tabular}{|c|c|c|c|c|c|}
\hline Criteria & $\begin{array}{l}\text { Excellent } \\
\text { (Green) }\end{array}$ & $\begin{array}{l}\text { Good } \\
\text { (Blue) }\end{array}$ & $\begin{array}{l}\text { Adequate } \\
\text { (Yellow) }\end{array}$ & $\begin{array}{l}\text { Po } \\
\text { or } \\
\text { (R } \\
\text { ed) }\end{array}$ & Total \\
\hline $\begin{array}{l}\text { SECTION } \\
\text { C: Maximize } \\
\text { benefits to } \\
\text { communities } \\
\text { and visitors, } \\
\text { minimize } \\
\text { negative } \\
\text { impacts }\end{array}$ & $61.54 \%$ & $\begin{array}{l}23.08 \\
\%\end{array}$ & $15.38 \%$ & $\begin{array}{l}0 . \\
00 \\
\%\end{array}$ & $\begin{array}{l}100 \\
\%\end{array}$ \\
\hline $\begin{array}{l}\text { SECTION } \\
\text { D: Maximize } \\
\text { benefits to } \\
\text { the } \\
\text { environment } \\
\text { and } \\
\text { minimize } \\
\text { negative } \\
\text { impacts }\end{array}$ & $21.43 \%$ & $\begin{array}{l}78.57 \\
\%\end{array}$ & $0.00 \%$ & $\begin{array}{l}0 . \\
00 \\
\%\end{array}$ & $\begin{array}{l}100 \\
\%\end{array}$ \\
\hline Sum \% & $43.81 \%$ & $\begin{array}{l}54 \\
51.43 \\
\%\end{array}$ & $4.76 \%$ & $\begin{array}{l}0 \\
0 . \\
00 \\
\%\end{array}$ & $\begin{array}{l}105 \\
100 \\
.00 \\
\%\end{array}$ \\
\hline
\end{tabular}

Source: FGD Results Data Processed

Based on the above table it is known that for section $\mathrm{A}$ has 23 items (53.49\%) with criteria implemented with green criteria, 17 items (39.53\%) with blue criteria, 3 items in yellow category and no items are in red category. This is quite an increase compared with baseline condition where in category A there are 18 items $(41,86 \%)$ with well implemented criteria (blue), 19 items $(44,19 \%)$ with yellow criteria and 6 item $(13,95 \%)$ with red criteria.

For section A based on baseline results, the highest scores are;1)crisis and emergency management, 2) destination management organization and 3) safety and security. The lowest scores include; 1) http://ojs.unud.ac.id/index.php/eot visitor satisfaction, 2) tourism seasonality management and 3) asset and attraction inventoryation. In the final assessment the results are; items with the highest value among others; 1) aspects of promotion, 2) crisis and emergency management and 3) destination management organization. The lowest score is; 1) property acquisitions, 2) asset \& attraction inventarisation and 3) tourism seasonality management.

In section $\mathrm{B}$ there are 9 items $(42,86 \%)$ in excellent category, 12 items $(57,14 \%)$ in good category, 0 item in adequate and poor category. It means that there is a significant improvement in the implementation of STD governance compared to baseline conditions, where there are 0 items in excellent category, 19 items $(41,86 \%)$ in good category, 19 items $(44,19 \%)$ in adeaquate category and 6 items $(13,95 \%)$ are in the poor category. While at the baseline the highest score among others on the indicator; 1) supporting local entrepreneurs and fair trade, 2) local career opportunities and 3) economic monitoring, in the final assessment the orders become; 1) supporting local entrepreneurs and fair trade, 2) local career opportunities and 3) economic monitoring. The lowest score among others; 1) local access, 2) tourism awareness and education and 3) support for community, then in the final transform e-ISSN: 2407-392X. p-ISSN: 2541-0857 
to 1) local access, 2) tourism awareness and education and 3) support for community.

For section $\mathrm{C}$ in the final assessment there were 8 items (61.54\%) which were very well impregnated (green), 3 items (23.08\%) were good executed, 2 items $(15.38 \%)$ were in adequate category and 0 items in poor category. This achievement also indicates an increase in the application of STD in section C. Previously there were only 0 items in the excellent category, 9 items $(69.23 \%)$ in good category, 3 items $(23.08 \%)$ in adequate category and 1 item $(7.69 \%)$ are in poor category. If at the baseline the highest score among others on the indicators; 1) site interpretation, 2) visitor behavior and 3) attraction protection, at baseline transform to;1) site interpretation, 2) visitor behavior and 3) cultural heritage protection. The lowest baseline scores include; 1) cultural heritage protection, 2) visitor management and 3) intellectual property, then in final assessment become 1) attraction protection, 2) visitor management and 3) intellectual property.

While in section D there are 6 items $(21,43 \%)$ are in excellent, 22 item $(78,57 \%)$ in good category, and each 0 item for good and adequate category. This condition improved significantly compared with the baseline result, where http://ojs.unud.ac.id/index.php/eot there were 0 items in the excellent category, 13 items $(46.43 \%)$ in good category, 14 items $(50 \%)$ in adequate category and 1 item $(3.57 \%)$ were in poor category. For section D based on the baseline result, the highest score among others on indicators; 1) protection of sensitive environments, 2) low-impact transportation, and 3) environtmental risk. In the final assessment the highest score occurs on 1) solid waste reduction items, 2) wastewater and 3) protection of sensitive environments. The lowest baseline scores include; 1) energy conservation, 2) water management and 4) water security,then change into 1) light and noise pollution, 2) low-impact transportation and 3) water management in the final asessment.

\section{Treatment Activities}

After the implementation of the baseline assessment activity, TSR is further informed about the importance of the application of sustainable tourism development. To induce TSR management with STD application the researcher performs a number of treatment stages, prior to final assessment, namely:

a) Implementing the socialization of tourism destination implementation with STD concept based on GSTC and Permenpar No.14 / 2016 criteria. 
b) Conducting mentoring and strengthening for each aspect related to the implementation of STD. Assistance activities are conducted on each relevant work unit.

c) Implementing the improvement of STD implementation in accordance with GSTC criteria with a duration of 3 months, by performing periodic evaluations per 2 weeks.

d) Conducting $\quad$ a final assessment.Include TSR on Indonesia Sustainable Tourism Award (ISTA) activities organized by Kemenpar RI in 2017. In this case the result is very encouraging because TSR can get recognition of ISTA Award as the 2nd best destination in environmental management and preservation (Alex, 2017).

\section{CONCLUSIONS AND SUGGESTIONS}

Some important things that can be concluded in this study are as follows:

1) The process of assistance and treatment of tourism destinations TSR has managed to improve the quality of governance of tourism destinations with the concept of STD. If the baseline is still minimal achievement implementation in the green and blue categories but in the

final assessment there is improvement so that the majority of indicators of the assessed variables into the category of green and blue as expected.

2) TSR basically has a good awareness and commitment in applying the concept of sustainable tourism development. STD-oriented activities in many ways have actually been implemented for a long time. Owners and management in a sustainable manner have tried to make good planning, empower the economy of the local community, preserve the culture and preserve the environment, but it must be admitted there are still many weaknesses and still need improvement continuously, along with the development of STD concept which for some key stakeholders is still considered as a novelty. The weakest of all observed aspects is the availability of reports and administrative documents that record the progress of improvement over time and need to optimize and increase synergies with local governments in particular and other stakeholders in general.

3) The implementation of sustainable tourism development is a journey and a long struggle and for better e-ISSN: 2407-392X. p-ISSN: 2541-0857 
implementation requires synergy of all parties (key stakeholders). As a leading tourist destination in the area of Lake Toba, the existence of TSR with excellence in applying STD should continue to get support from all parties and TSR can be used as a local champion in the area of Lake Toba as a destination that implements the development of tourism development.

4) Further research needs to be done to see the implementation of STD on a wider spectrum especially for Lake Toba area which is currently being hit by various negative issues such as environmental pollution, forest fire, transportation security, economic empowerment of local communities and others.

\section{REFERENCE}

Afriza, L., Kartika, T. dan Riyanti, A. (2018) "Pengembangan Ekowisata Berbasis Masyarakat (Community Based Ecotourism) dalam Rangka Mengentaskan Kemiskinan di Desa Karongsong Kabupaten Indramayu," Jurnal Sains Terapan Pariwisata, 3(1), hal. 20-34. Tersedia pada: http://www.journal.stpsahid.ac.id/ind ex.php/jstp/article/view/128 (Diakses: 14 Juli 2018).
Akama, J. S. dan Kieti, D. (2007) "Tourism and Socio-economic Development in Developing Countries: A Case Study of Mombasa Resort in Kenya," Journal of Sustainable Tourism, 15(6), hal. 735-748. doi: 10.2167/jost543.0.

Alex (2017) Taman Simalem Resort Juara II ISTA, Harian Analisa. Tersedia pada:

http://harian.analisadaily.com/sumut/ news/taman-simalem-resort-juara-iiista/423870/2017/09/30 (Diakses: 14 Juli 2018).

Amerta, I. M. S., Sara, I. M. dan Bagiada, K. (2018) "Sustainable Tourism Development," International Research Journal of Management, IT and Social Sciences (IRJMIS), 5(2), hal. 248-254. Tersedia pada: https://ijcujournals.us/journals/index. php/irjmis/article/view/176.

Bassi, A. dan Sheng, F. (2012) Measuring Progress Towards an Inclusive Green Economy. Nairobi: United Nations Environment Programme (UNEP), United Nations Environment programme (UNEP). Nairobi.

Blancas, F. J. et al. (2010) "The assessment of sustainable tourism: Application to Spanish coastal destinations," Ecological Indicators, 10(2), hal. 484-492. doi: 10.1016/j.ecolind.2009.08.001.

Butler, R. W. (1999) "Sustainable tourism: A state-of-the-art review," Tourism Geographies, 1(1), hal. 7-25. doi: $10.1080 / 14616689908721291$.

Castellani, V. dan Sala, S. (2010) "Sustainable performance index for tourism policy development," Tourism Management. Elsevier Ltd, 31(6), hal. 871-880. doi: 10.1016/j.tourman.2009.10.001. 
Dergibson dan Siagian, S. (2006) Metode Statistika untuk Bisnis dan Ekonomi.

Dewipule (2015) Pulesari Menjadi Pilot Project, 20 Destinasi di Indonesia, Wordpress. Tersedia pada: https://desawisatapulesari.wordpress. com/2016/02/01/pulesari-menjadipilot-project-proiritas-20-destinasidi-indonesia/ (Diakses: 6 Juli 2018).

Fennell, D. A. (2014) Ecotourism. 4 ed. Routledge. Tersedia pada: https://books.google.co.id/books?hl= $\mathrm{id} \& 1 \mathrm{r}=\& \mathrm{id}=\mathrm{oYmbBAAAQBAJ} \& \mathrm{oi}=$ fnd\&pg=PP1\&ots=geUzOG5MHP\& sig=DZbSupAQJzE9J5ENhyuXqOE E6w4\&redir_esc $=\mathrm{y} \# \mathrm{v}=$ onepage \&q\& $\mathrm{f}=$ false (Diakses: 6 Juli 2018).

\section{GSTC (2017) GSTC Criteria - Global Sustainable Tourism Council (GSTC). Tersedia pada: https://www.gstcouncil.org/gstc- criteria/ (Diakses: 30 November 2017).}

Hák, T., Janoušková, S. dan Moldan, B. (2016) "Sustainable Development Goals: A need for relevant indicators," Ecological Indicators, 60, hal. 565-573. doi: 10.1016/j.ecolind.2015.08.003.

Hardy, A., Beeton, R. J. S. dan Pearson, L. (2002) "Sustainable tourism: An overview of the concept and its position in relation to conceptualisations of tourism," Journal of Sustainable Tourism, 10(6), hal. 475-496. doi: $10.1080 / 09669580208667183$.

Heinen, J. T. (1994) "Emerging, diverging and converging paradigms on sustainable development," International Journal of Sustainable Development and World Ecology, 1(1), hal. 22-33. doi: $10.1080 / 13504509409469857$.
Hulme, D. (2009) A Short History of the World 's Biggest Promise September 2009 BWPI Working Paper 100.

Hunter, C. J. (1995) "On the Need to ReConceptualise Sustainable Tourism Development," Journal of Sustainable Tourism. Taylor \& Francis Group, 3(3), hal. 155-165. doi: 10.1080/09669589509510720.

Ibo, A. (2015) 10 Destinasi Wisata Prioritas di Tahun 2016, Liputan 6. Tersedia pada: https://www.liputan6.com/lifestyle/r ead/2401196/10-destinasi-wisataprioritas-di-tahun-2016 (Diakses: 6 Juli 2018).

Kemenpar (2016) Peraturan Menteri Pariwisata Republik Indonesia No.14 Tahun 2016 Tentang Pedoman Destinasi Pariwiata Bekelanjutan. Tersedia pada: http://kemenpar.go.id/asp/detil.asp?c =38\&id=3290 (Diakses: 30 November 2017).

Kominfo (2016) 10 Destinasi Pariwisata Prioritas 2016, Kementerian Komunikasi dan Informatika Republik Indonesia. Tersedia pada: https://kominfo.go.id/index.php/cont ent/detail/7513/10-destinasipariwisata-prioritas2016/0/infografis (Diakses: 6 Juli 2018).

Kristjánsdóttir, K. R., Ólafsdóttir, R. dan Ragnarsdóttir, K. V. (2018) "Reviewing Integrated Sustainability Indicators for Tourism," Journal of Sustainable Tourism. Routledge, 26(4), hal. 583-599. doi: 10.1080/09669582.2017.1364741. 
Kumar, A. et al. (2017) "A Review of Multi Criteria Decision Making (MCDM) Towards Sustainable Renewable Energy Development," Renewable and Sustainable Energy Reviews. Pergamon, 69, hal. 596609. doi: 10.1016/J.RSER.2016.11.191.

Lane, B. (1994) "Sustainable rural tourism strategies: A tool for development and conservation," Journal of Sustainable Tourism, 2(1-2), hal. 102-111. doi: $10.1080 / 09669589409510687$.

Law, A., DeLacy, T. dan McGrath, G. M. (2017) "A Green Economy Indicator Framework for Tourism Destinations," Journal of Sustainable Tourism. Taylor \& Francis, 25(10), hal. 1434-1455. doi: 10.1080/09669582.2017.1284857.

Lele, S. M. (1991) "Sustainable development: a critical review," World Development, 19(6), hal. 607621. doi: 10.1016/0305750X(91)90197-P.

Liu, Z. (2003) "Sustainable Tourism Development: A Critique," Journal of Sustainable Tourism. Taylor \& Francis Group, 11(6), hal. 459-475. doi: 10.1080/09669580308667216.

Nam, U. (2016) Transforming our world: the 2030 Agenda for Sustainable Development, UNDP Viet Nam Natural Capital Platform. Tersedia pada:

http://www.naturalcapital.vn/wpcontent/uploads/2017/02/UNDP-

Viet-Nam.pdf (Diakses: 30 November 2017).
Nowacki, M. et al. (2018) "Strategic Planning for Sustainable Tourism Development in Poland," International Journal of Sustainable Development \& World Ecology. Taylor \& Francis, 25(6), hal. 562567. doi: 10.1080/13504509.2018.1432513.

Nurhidayati, S. E. (2007) "Community Based Tourism (CBT) sebagai Pendekatan Pembangunan Pariwisata Berkelanjutan," Jurnal Masyarakat, Kebudayaan, dan Politik Universitas Airlangga, Th XX 3, hal. 191-202. Tersedia pada: http://www.journal.unair.ac.id/filerP DF/Community Based Tourism _CBT_.pdf (Diakses: 14 Juli 2018).

OECD (2014) "Green Growth Indicators 2014." OECD Green Growth Studies. doi: https://doi.org/10.1787/9789264202 030-en.

Ottenbacher, M. C. et al. (2018) "Sustainability Criteria for Tourism Attractions: A Case Study of Germany. In Sustainable Development: Concepts, Methodologies, Tools, and Applications," in IGI Global, hal. 1526-1548. Tersedia pada: https://www.igiglobal.com/chapter/sustainabilitycriteria-for-tourismattractions/189957.

Paunović, I. dan Jovanović, V. (2017) "Implementation of Sustainable Tourism in the German Alps: A Case Study," Sustainability. Multidisciplinary Digital Publishing Institute, 9(2), hal. 226. doi: $10.3390 /$ su9020226. 
Peng, K.-H. dan Tzeng, G.-H. (2017) "Exploring Heritage Tourism Performance Improvement for Making Sustainable development strategies using the hybrid-modified MADM model," Current Issues in Tourism. Routledge, hal. 1-27. doi: 10.1080/13683500.2017.1306030.

Ritchie, J. R. B. dan Crouch, G. I. (2003) The Competitive Destination: A Sustainable Tourism Perspective - J. R. Brent Ritchie, Geoffrey Ian Crouch - Google Buku. Cabi. Tersedia pada: https://books.google.co.id/books?hl= $\mathrm{id} \& \mathrm{lr}=\& \mathrm{id}=\mathrm{y}$ ydAwAAQBAJ $\&$ oi $=\mathrm{f}$ nd\&pg=PR5\&dq=Ritchie + dan + Crou ch+The+Competitive+Destination+ \&ots=lRKVbnncYJ\&sig=f6Je7Z2B KKYGX1Zc4k3Lnx75JZ8\&redir_es $\mathrm{c}=\mathrm{y} \# \mathrm{v}=$ onepage $\& \mathrm{q}=$ Ritchie $\quad$ dan Crouch The Competitive Destination\&f=f (Diakses: 17 Juli 2018).

Rizkianto, N. dan Topowijono, T. (2018) "Penerapan Konsep Community Based Tourism dalam Pengelolaan Daya Tarik Wisata Berkelanjutan (Studi Pada Desa Wisata Bangun, Kecamatan Munjungan, Kabupaten Trenggalek)," Jurnal Administrasi Bisnis, 58(1). Tersedia pada: http://administrasibisnis.studentjourn al.ub.ac.id/index.php/jab/article/view /2402 (Diakses: 14 Juli 2018).

Dos Santos, R. A., Méxas, M. P. dan Meiriño, M. J. (2017) "Sustainability and Hotel Business: Criteria for Holistic, Integrated and Participative Development," Journal of Cleaner Production. Elsevier, 142, hal. 217224. doi: 10.1016/J.JCLEPRO.2016.04.098.
Seaford, C. dan Jeffrey, K. (2015) Headline Indicators of Progress for a Green Economy. NETGREEN Network for Green Economy Indicators - Policiy Brief. Tersedia pada: file:///D:/0008 - P E N E L I T I A N/2017a - tata kelola tsr dengan STD 10j ess/000 - Proposal 2017 STD/NETGREEN_PolicyBrief_Hea dlineIndicators2015.pdf.

Singh, M. (2018) "Sustainable development of tourism in Uttarakhand, (India)," International Journal of Academic Research and Development, 3(2), hal. 828-831.

Steer, A. dan Wade-Gery, W. (1993) "Sustainable Development: Theory and Practice for a Sustainable Future," Sustainable Development. Wiley-Blackwell, 1(3), hal. 23-35. doi: 10.1002/sd.3460010306.

Torres-Delgado, A. dan López Palomeque, F. (2017) "The ISOST index: A tool for studying sustainable tourism," Journal of Destination Marketing \& Management. Elsevier. doi: 10.1016/J.JDMM.2017.05.005.

Tosun, C. (2001) "Challenges of sustainable tourism development in the developing world: The case of Turkey," Tourism Management, 22(3), hal. 289-303. doi: 10.1016/S0261-5177(00)00060-1.

Tribe, J. (2011) The Economics of Recreation, Leisure and Tourism. Routledge. doi: 10.4324/9780080890517.

UNEP dan UNWTO (2005) Making Tourism More Sustainable - A Guide for Policy Makers, UNWTO. Tersedia pada: http://sdt.unwto.org/content/aboutus-5 (Diakses: 17 Juli 2018). 
WECD, S. W. S. (1987) "World Commission on Environment and Development - Our Common Future."

Wysokinska, Z. (2017) "Millenium Development Goals/UN and Sustainable Development Goals/UN as Instruments for Realising Sustainable Concept in the Global Economy," Comparative Economic Research, 20(1).

Wysokińska, Z. (2017) "Millenium Development Goals/UN and Sustainable Development Goals/UN as Instruments for Realising Sustainable Development Concept in the Global Economy," Comparative Economic Research. De Gruyter Open, 20(1), hal. 101-118. doi: 10.1515/cer-2017-0006. 